\title{
Geochemical investigation of hydrocarbon generation potential of coal from Raniganj Basin, India
}

\author{
D. S. Panwar ${ }^{1,2} \cdot$ Ram Chandra Chaurasia $^{1,3} \cdot$ V. K. Saxena ${ }^{1} \cdot$ A. K. Singh ${ }^{4} \cdot$ Akanksha $^{5}$
}

Received: 9 May 2021 / Accepted: 28 August 2021 / Published online: 4 September 2021

(C) The Author(s) 2021

\begin{abstract}
Methane content in a coal seam is a necessary parameter for evaluating coal bed gas, and it poses an environmental risk to underground coal mining activities. Keeping in pace with comprehensive studies of coal bed gas, 12 coal samples were selected from the Sitarampur block of Raniganj Coalfield for analysis. The Petrographic examination illustrated that significant values of reactive macerals present in samples demonstrate that organic matter is dominated by the prominent source of aromatic hydrocarbons with a minor proportion of aliphatic hydrocarbon, which falls in the region of (Type III) kerogen, confirms the suitability for the potential of hydrocarbon generation. "A" factor (aliphatic/aromatic bands) and " $\mathrm{C}$ " factor (carbonyl/carboxyl bands) value concluded that the sample has the lowest aromaticity and the highest hydrocarbon-generating potential, which was also validated by the Van Krevelen diagram. The Van Krevelen diagram plots between the H/C and $\mathrm{O} / \mathrm{C}$ ratio indicate that coal samples lie in the type III kerogen, and bituminous coal (gas prone zone) is present in the block, which is confirmed by the cross-plot between desorbed and total gas $(\mathrm{cc} / \mathrm{g})$. The in situ gas content values are high enough to produce methane from coal beds. The overall study concludes that the Sitarampur block from Raniganj Coalfield is suitable for hydrocarbon generation and extraction.
\end{abstract}

Keywords Hydrocarbon generation potential · Petrographic study $\cdot$ In situ gas content · Oil yield · Kerogen type · Fourier Transform Infrared spectrometry analysis

\section{Introduction}

Natural gas discoveries have been made in many basins around the world, and governments are paying close attention and focusing on exploration (Abudeif et al. 2016; Attia et al. 2015; Radwan et al. 2021). Natural gas has become a promising substitute for coal and plays a significant role in

D. S. Panwar

deepaksingh.4268@gmail.com

1 Department of Fuel, Minerals and Metallurgical Engineering, IIT (ISM), Dhanbad 826004, India

2 Department of Chemical Engineering, P P Savani University, Surat 394125, India

3 Department of Chemical Engineering, S N Patel Institute of Technology and Research Centre. Umrakh, Gujarat 394601, India

4 Department of Methane Emission and Degasification, CSIR-CIMFR, Dhanbad 826001, India

5 Department of Chemical Engineering, NIT Rourkela, Rourkela 769001, India power generation and other alternative sources of energy in different applications in India (CEA 2019). The demand for natural gas in India is steadily increasing over the past few decades from 49.10 to 59.70 billion cubic feet (BP 2020). In India, natural gas consumption grew continuously, with an annual rate of $6.2 \%$ between 2000 and 2019 (MPNG 2020). In the last few decades, natural gas production from coal beds has experienced rapid development in many countries such as the USA, Australia, China, India, and Canada (Panwar et al. 2016a, 2016b, 2020). When the methane is recovered simultaneously with coal during underground mining of coal, it is known as coal mine methane (CMM). Coal mine methane mining is done to reduce methane concentration in the mines and working areas around the mines for its effective utilization of coal and CMM. Methane is the principal gas in CMM with varying concentrations from 25-60\% (Karacan 2009) and must be released or vented for safety reasons. So, CMM is an unconventional form of natural gas found in association with coal seams, and it is a clean burning fuel with a good heating value $>8500 \mathrm{kcal} /$ Kg. (Ojha et al. 2013; Panwar et al. 2017a, 2017b, 2017c). 
The literature reveals that coal is a sedimentary rock, with complex pore and fracture structure (Gao et al. 2014). The macro-micro pores in coal provide extremely massive surface areas for methane, and it accumulates as a free, adsorbed, and dissolved state (Kumar et al. 2018; Wang et al. 2020). The different ranks of coal, mineral matter and maceral composition significantly influence the methane sorption capacity (Goraya et al. 2019; Moore et al. 2014). The literature reveals that Fourier transform infrared spectroscopy (FTIR) is extensively employed to characterize various source rocks to determine hydrocarbon generation potential (Ganz and Kalkreuth 1991; Mishra et al. 2018; Varma et al. 2018). The FE-SEM and EDX analysis were significantly used for organic matter association with mineral matter and coal surface structure.

In the current investigation, the author's tried to analyze the petrographic composition, geochemical characteristics, organic richness, oil generation potential, thermal maturity, liquefaction behavior, and hydrocarbon generation potential for Gondwana coals belonging to Barakar formations in Raniganj Basin, which is the primarily targeted basin for hydrocarbon productions (CBM) in India. This investigation may be serving as a guide for future deep hydrocarbon resource evaluation.

\section{Methods of experiment and analysis}

A total of 12 coal core samples were collected from one borehole during the exploratory drilling in different five coal seams present in the Sitarampur block. The Sitarampur Coal Block is situated in Raniganj coalfield in Burdwan District, West Bengal, India, having coordinates with Latitude N $23^{\circ} 43^{\prime} 25^{\prime \prime}$ to $\mathrm{N} 23^{\circ} 45^{\prime} 28.11^{\prime \prime}$ and Longitude E $86^{\circ} 51^{\prime} 23^{\prime \prime}$ to E $86^{\circ} 53^{\prime} 28.16^{\prime \prime}$ as shown in Fig. 1 along with geological setting such as age, group and formation. However, the methodology adopted and equipment used for the characterization of the sample are shown in Table 1.

\section{Proximate analysis}

Proximate analysis was carried out in the IIT (ISM), Dhanbad, by following the standard procedure of the Bureau of Indian Standard [BIS Standard: 1350, Part-1, 2003] were used. For analysis, $-212 \mu$ size of coal was prepared, and $1 \mathrm{~g}$ of coal was taken for each analysis, and it was used for the determination of ash content, moisture, and volatile matter of coals.

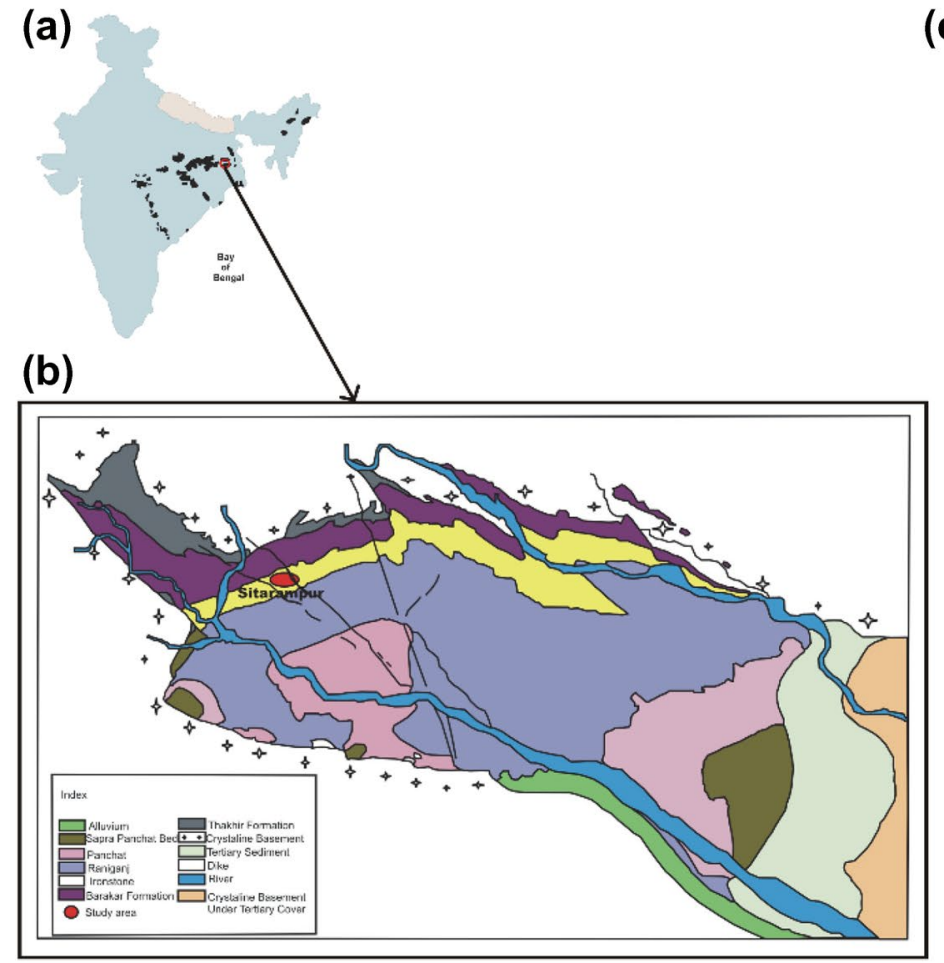

(c)

\begin{tabular}{|c|c|c|}
\hline Age & Group & Formation \\
\hline $\begin{array}{l}\text { Recent, } \\
\text { Sub Recent } \\
\text { \& Quaternary }\end{array}$ & & $\begin{array}{l}\text { Alluvia Soil, } \\
\text { Clays, loose sand etc. }\end{array}$ \\
\hline \multicolumn{3}{|c|}{ 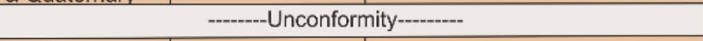 } \\
\hline Jurassic & $\begin{array}{l}\text { Intrusives } \\
\text { (Dykes\& Sills) }\end{array}$ & $\begin{array}{l}\text { Dolerite, Mica-peridotite } \\
\text { \& Lamprophyres }\end{array}$ \\
\hline $\begin{array}{l}\text { Middle/Upper } \\
\text { Triassic }\end{array}$ & Supra-Panchet & $\begin{array}{l}\text { Coarse grained quartzose } \\
\text { sandstone with bands of dark } \\
\text { red silty shale }\end{array}$ \\
\hline \multicolumn{3}{|c|}{-----Unconformity------ } \\
\hline $\begin{array}{l}\text { Lower } \\
\text { Triassic }\end{array}$ & Panchet & $\begin{array}{l}\text { Coarse grained, grey } \\
\text { sandstone, brownish to } \\
\text { reddish clay and khaki green } \\
\text { fissile shale }\end{array}$ \\
\hline $\begin{array}{l}\text { Upper } \\
\text { Permian }\end{array}$ & Raniganj & $\begin{array}{l}\text { Fine to coarse grained, } \\
\text { micaceous sandstones, shale } \\
\text { and coal seams }\end{array}$ \\
\hline $\begin{array}{l}\text { Middle } \\
\text { Permian }\end{array}$ & $\begin{array}{l}\text { Barren } \\
\text { Measures }\end{array}$ & $\begin{array}{l}\text { Dark grey to brown, laminated } \\
\text { fissile shales, shale and } \\
\text { sandstone alternation and clays } \\
\text { with sideritic nodules and bands }\end{array}$ \\
\hline $\begin{array}{l}\text { Lower } \\
\text { Permian }\end{array}$ & Barakars & $\begin{array}{l}\text { Coarse grained felspatic } \\
\text { sandstone, shales, carbonaceous } \\
\text { shales and coal seams }\end{array}$ \\
\hline $\begin{array}{l}\text { Upper } \\
\text { carbonaceous }\end{array}$ & Talchirs & $\begin{array}{l}\text { Greenish sandstone and } \\
\text { needle shales }\end{array}$ \\
\hline \multicolumn{3}{|c|}{----Unconformity----- } \\
\hline Pre- Cambrian & Archaeans & $\begin{array}{l}\text { Gneisses and schists with } \\
\text { quartz veins }\end{array}$ \\
\hline
\end{tabular}

Fig. 1 Sitarampur block location in map 
Table 1 Tests adopted for coal sample characterization

\begin{tabular}{llll}
\hline Name of experiment & Equipment & Size of sample & Institute \\
\hline Proximate analysis & $\begin{array}{c}\text { Oven for Moisture and Muffle furnace for } \\
\text { ash and volatile content measurement }\end{array}$ & -72 BSS mesh & IIT (ISM) Dhanbad \\
Ultimate analysis & Vario Macro Cube CHNS analyzer & -72 BSS mesh & IIT (ISM) Dhanbad \\
SEM-EDX & FE-SEM Supra 55 (Carl Zeiss, Germany) & -72 BSS mesh & IIT (ISM) Dhanbad \\
FTIR spectroscopy & Perkin Elmer Spectra 2, USA & -72 BSS mesh & IIT (ISM) Dhanbad \\
Petrographic analysis & Petrographic microscope & - & IIT (ISM) Dhanbad \\
\hline
\end{tabular}

\section{Ultimate analysis}

The elemental analysis of coal core samples collected from different seams of the Sitarampur block of Raniganj coalfield was analyzed by the elemental analyzer (Elementar Vario EL III-CHNS analyzer) in the IIT (ISM), Dhanbad. For analysis, $-212 \mu$ size of coal was prepared, and $1 \mathrm{~g}$ of coal was taken for the analysis of $\mathrm{C}, \mathrm{H}, \mathrm{N}$, and $\mathrm{S}$.

\section{Petrographic analysis}

Coal petrography for collected coal samples were carried out at the Department of Applied Geology, IIT (ISM), Dhanbad. Maceral groups were identified. Subsequently, estimation of vitrinite reflectance (Goraya et al.) has been done in oil medium on polished coal surface in reflectance with white light and fluorescence illumination under an advanced research polarizing microscope using Leica DMRXP-HC setup. Besides this, the Bureau of Indian Standards was followed to prepare the sample [BIS No 9127 part 2 for preparation, grinding and polishing of pellet, part 3 for maceral and mineral identification and part 5 for VRo measurement].

\section{Fourier Transform Infrared spectrometry (FTIR) analysis}

For FTIR spectroscopy, samples were prepared in the form of pellets, following the procedures outlined by Painter et al. (Painter et al. 1981). Dried pellets were used to reduce the contribution of water over the spectrum. FTIR of the coal samples was carried out in a wavelength frequency range of $4000 \mathrm{~cm}^{-1}$ to $200 \mathrm{~cm}^{-1}$ in absorbance mode. A 3000 Hyperion Microscope with Vertex 80 made by Bruker optics, Germany, was used for FTIR analysis.

\section{Measurement of coal seam gas content}

\section{Direct method}

There are mainly three steps involved in measuring the in situ gas content of coal core samples retrieved from exploratory boreholes. Lost gas denoted by $\mathrm{Q}_{1}$ is the amount of gas lost by the core sample since its extraction from undisturbed coal seam to its confinement in the desorption canister. The cumulative value obtained by desorbed gas volume measurement gave desorbed gas $\left(\mathrm{Q}_{2}\right)$ for the coal samples. From the measured volume of gas obtained after crushing a portion of the samples, the residual gas $\left(\mathrm{Q}_{3}\right)$ was calculated for the total weight of the samples. The total volume of gas obtained by the addition of $\mathrm{Q}_{1}, \mathrm{Q}_{2}$, and $\mathrm{Q}_{3}$ is divided by the total weight of the sample.

$\mathrm{Q}=\mathrm{Q}_{1}+\mathrm{Q}_{2}+\mathrm{Q}_{3}$

\section{Result and discussion}

\section{Hydrocarbon generation potential}

The petrographic study is predominantly used for the determination of kerogen type and its suitability for hydrocarbon generation. In previous studies, many researchers reveal that Vitrinite and liptinite macerals are generally used as an indicator for the determination of hydrocarbon generation potential (Akanksha et al. 2020; Panwar et al. 2020; Tissot and Welte 1984). The hydrocarbon generation potential of the Sitarampur block was assessed using petrographic data. The samples have significant values of reactive macerals and liptinite content in the range of 67.57 to $81.10 \mathrm{vol} . \%$ and 5.24 to $10.05 \mathrm{vol} . \%$, respectively, making them suitable for hydrocarbon generation (Akanksha et al. 2017; Kotarba et al. 2002; Varma et al. 2019). The Petrographic examination illustrated that type III kerogen present in studied samples, as shown in Fig. 2. The ternary plot of petrographic constituents indicates that samples are vitrinite ample and mature. It was also deduced from the study that there is also a possibility of excellent hydrocarbon (methane) generation potential in coal, as shown in Fig. 3 .

Empirical equations are given by Guyot (Guyot 1978; Jin and Shi 1997) used for assessment of the conversion of coal into oil and oil yield.

$\mathrm{RF}=\frac{1000 \mathrm{R}_{\max }}{\mathrm{RM}}$

Conversion $(\%)=0.2 R M+76.6$ 


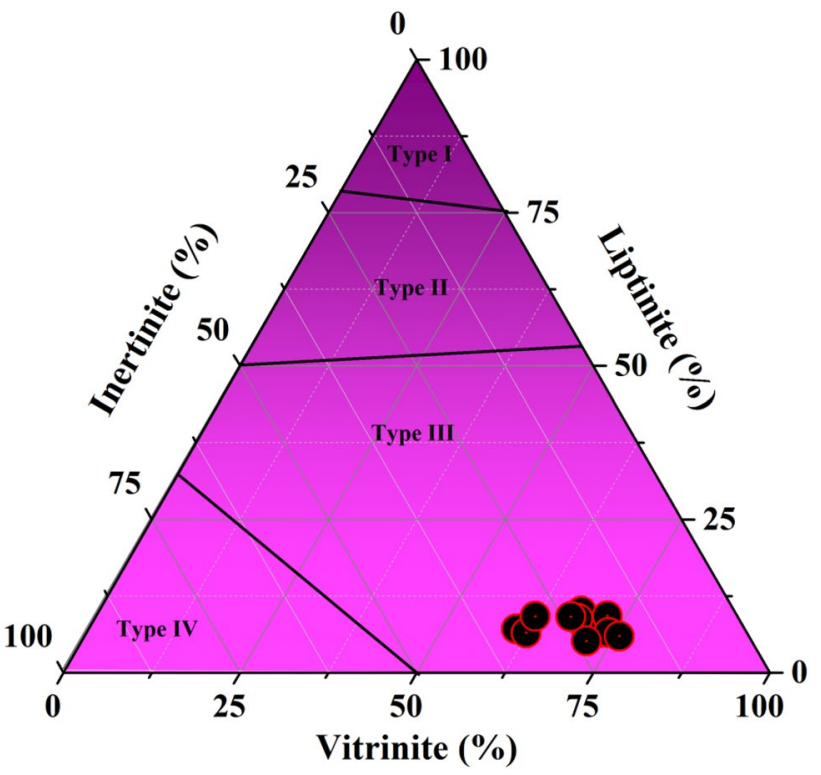

Fig. 2 Ternary diagram of maceral composition indicating kerogen types of samples

Oilyield $(\%)=0.22 R M+44.8$

where $\mathrm{R}_{\max }$ indicates huminite maximum reflectance, $\mathrm{RM}$ indicate reactive macerals.

The coal samples demonstrate prominent values of conversion (\%) and oil yield (\%) in the range of 90.11 to 92.82 vol.\% and 59.67 to 62.64 vol.\%, respectively. It was also depicted from the study that emphasis correlations were

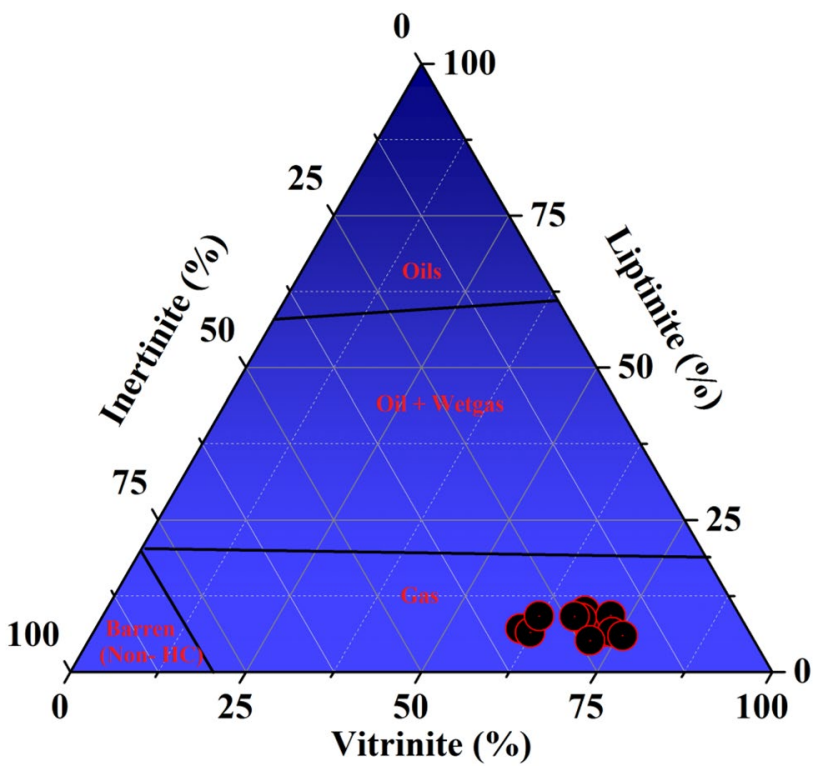

Fig. 3 Hydrocarbon potential based on petrographic components for representative samples found in conversion (\%) with vitrinite (\%) and oil yield (\%), as illustrated in Figs. 4 and 5.

\section{Petrographic investigations}

The petrographic analysis indicates the quantity of organic content, maturity, gas generation, and storage capacity in coal (Goraya et al. 2019; Kumar et al. 2018). It was also significantly utilized to determine coal formation and diagenesis (Gao et al. 2014; Moore 2012). The macroscopic petrography of the coal seams is mainly bright coal with black color, obvious black streaks (Gao et al. 2014; Moore 2012). The studied samples are mainly bright, vitreous luster and black in color, amorphous in nature, and fine-grained. The quantitative distribution of different macerals like vitrinite, liptinite, and inertinite is shown in Table 2. The microphotographs of various macerals and their associated subgroups are illustrated in Fig. 6.

A ternary facies of various macerals and mineral matter content was plotted. The studied samples mostly fall in the E field. The ternary diagram also exemplifies that they were deposited in alternating oxic (dry) moor with sudden high flooding during peat accumulation, as shown in Fig. 7 (Esen et al. 2020; Kumar et al. 2018). The vitrinite groups of macerals are dominantly present in samples, primarily derived from woody plant tissue, and its value varies from 59.47 to 73.39 vol.\% (averaging 66.43\%) on a dry ash-free basis (Varma et al. 2015a; Varma et al. 2015b). The liptinite is generally derived from waxy or resinous plant parts, and its value varies in samples from 5.24 to 10.05 vol.\% (averaging $7.64 \%$ ) on a dry ash-free basis. The carbon-rich inertinite groups are found in moderate

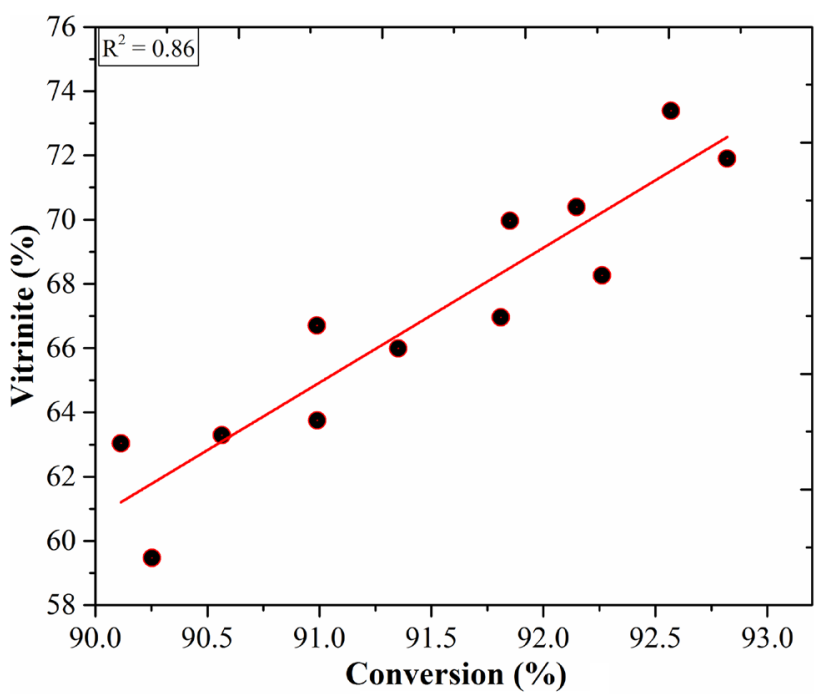

Fig. 4 Correlation between conversion (\%) and vitrinite (\%) for studied samples 


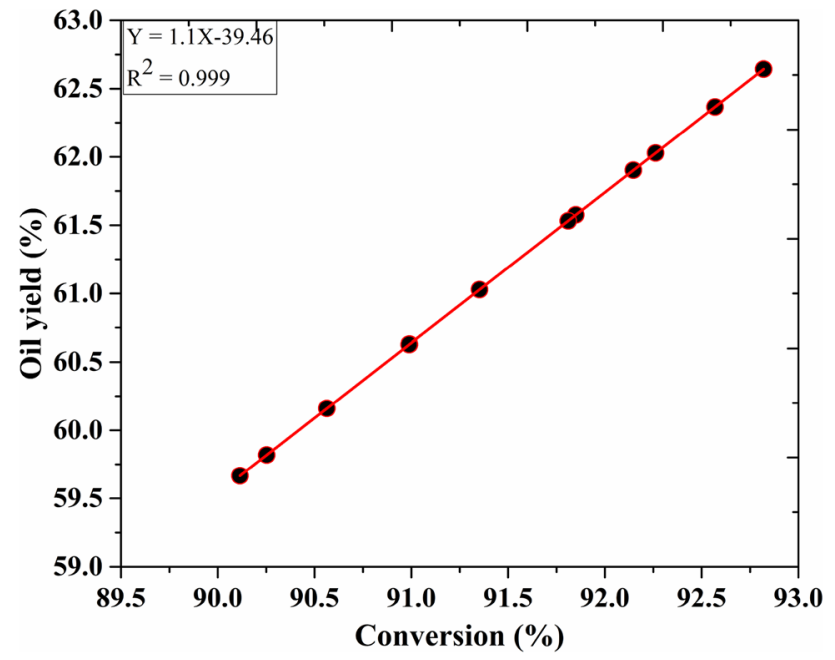

Fig. 5 Correlation between conversion and oil yield for studied samples

quantity, and their values ranging from 16.18 to 35.31 vol.\% (averaging $25.74 \%$ ) on a dry ash-free basis. The moderate value of inertinite content indicates that studied samples were formed under an exposed peat swamps environment (Fu et al. 2016; Wang et al. 2020). It was observed in several studies that the depth, organic matter, and rank enhance the gas potential of coal seams. The vitrinite reflectance value of studied samples varies from $1.08-1.38 \%$ and indicates the existence of bituminous with a significant quantity of methane in the block (Hou et al. 2016; Li et al. 2020).

\section{Assessment of gas content}

Methane is found in coal bed as absorbed and adsorbed from the latter constitutes $90 \%$ of the total amount of gas (Evans et al. 2020; Yee et al. 1993). The quantity of gas present in coal is known as gas content, and it depends on coal geology, seam thickness, depth of burial, igneous intrusions, and bounding strata type (Crosdale et al., 1998; Kiani et al., 2018; Yan et al., 2020). Methane evolution in coal is a two-step process biogenic (microbial activity) and thermogenic (cracking of organic matter). Gases generated in the succeeding thermogenic stage could migrate due to high-pressure regimes and remain stored in the coal (Altowilib et al. 2020). The pore and fracture systems were developed in coal during maturation. The micro-pore systems significantly control the gas's storage and flow in the coal matrix (Moore et al., 2014; Sharma et al., 2019). Methane is trapped in pores and fractures in the free, adsorbed, and dissolved states. Some of the microscopic images of the pore and fracture system are shown in Fig. 8. Modified USBM Direct Method was used for the measurement of in situ gas content. The total gas content of samples ranged from 2.09 to $11.64(\mathrm{cc} / \mathrm{g})$ on a dry ash-free basis, whereas residual gas content varies from 0.17 to 1.07 (cc/g) at standard condition (STP). The lost gas of the studied sample varied from 0.07 to $0.52(\mathrm{cc} / \mathrm{g})$ on a dry ash-free basis (Table.2). The desorbed gas content varies from 1.37 to $10.18(\mathrm{cc} / \mathrm{g})$ on a dry basis. The study also depicted that emphasis correlations were found between desorbed gas and total gas, as illustrated in Fig. 9. The study also revealed that total gas content value increases with desorbed gas, which may be due to the high desorption rate of studied samples in the field.

Table 2 Maceral analysis and In situ gas of studied coal samples

\begin{tabular}{llllllllll}
\hline Sample No & Vitrinite $(\%)$ & Liptinite $(\%)$ & Inertinite $(\%)$ & Ro $(\%)$ & Wt $(\mathrm{g})$ & $\mathrm{Q}_{1}(\mathrm{cc} / \mathrm{g})$ & $\mathrm{Q}_{2}(\mathrm{cc} / \mathrm{g})$ & $\mathrm{Q}_{3}(\mathrm{cc} / \mathrm{g})$ & $\mathrm{Q}_{(\mathrm{cc} / \mathrm{g})}$ \\
\hline 1 & 63.29 & 6.53 & 20.16 & 1.28 & 1210 & 0.46 & 2.99 & 0.21 & 3.67 \\
2 & 65.99 & 7.77 & 35.25 & 1.23 & 1090 & 0.37 & 2.76 & 0.21 & 3.34 \\
3 & 69.97 & 6.29 & 20.26 & 1.38 & 1050 & 0.07 & 2.65 & 0.17 & 2.89 \\
4 & 70.40 & 7.34 & 35.31 & 1.08 & 1440 & 0.21 & 6.85 & 0.51 & 7.58 \\
5 & 59.47 & 8.79 & 27.40 & 1.20 & 1640 & 0.25 & 1.37 & 0.47 & 2.09 \\
6 & 68.26 & 10.05 & 21.69 & 1.23 & 990 & 0.52 & 4.08 & 0.33 & 4.93 \\
7 & 63.75 & 8.20 & 21.18 & 1.21 & 1390 & 0.26 & 7.04 & 0.22 & 7.52 \\
8 & 66.96 & 9.09 & 23.50 & 1.19 & 1160 & 0.37 & 7.82 & 0.43 & 8.62 \\
9 & 71.90 & 9.20 & 18.28 & 1.25 & 1130 & 0.44 & 7.84 & 0.40 & 8.68 \\
10 & 73.39 & 6.46 & 19.38 & 1.13 & 1170 & 0.41 & 8.32 & 0.33 & 9.06 \\
11 & 66.71 & 5.24 & 16.18 & 1.09 & 1170 & 0.51 & 9.46 & 0.96 & 10.92 \\
12 & 63.04 & 4.54 & 20.63 & 1.31 & 1110 & 0.39 & 10.18 & 1.07 & 11.64 \\
\hline
\end{tabular}

Ro- Vitrinite Reflectance; Wt- Weight of the sample (gram); Q ${ }_{1}$ - Lost Gas (cc/g); $\mathrm{Q}_{2}$ - Desorbed Gas (cc/g); $\mathrm{Q}_{3}$-Residual Gas (cc/g); Q- Total gas content (cc/g) 
Fig. 6 Description: Representative photomicrographs of macerals of Raniganj Bituminous coal. Figure (A) shows bed of vitrinite [Vt] and inertinite[It] macerals; frame (B) shows sporenite[Sp] and cutinite $[\mathrm{Cu}]$ macerals of liptinite group, under fluorescence light; (C) frame of telenite[Tl] and (D) semifusinite[Sf] macerals; (E) groundmass of telovitrinite[Tv] with inertodetrinite[Id]; (F) bed of fusinite $[\mathrm{Fu}]$ macerals
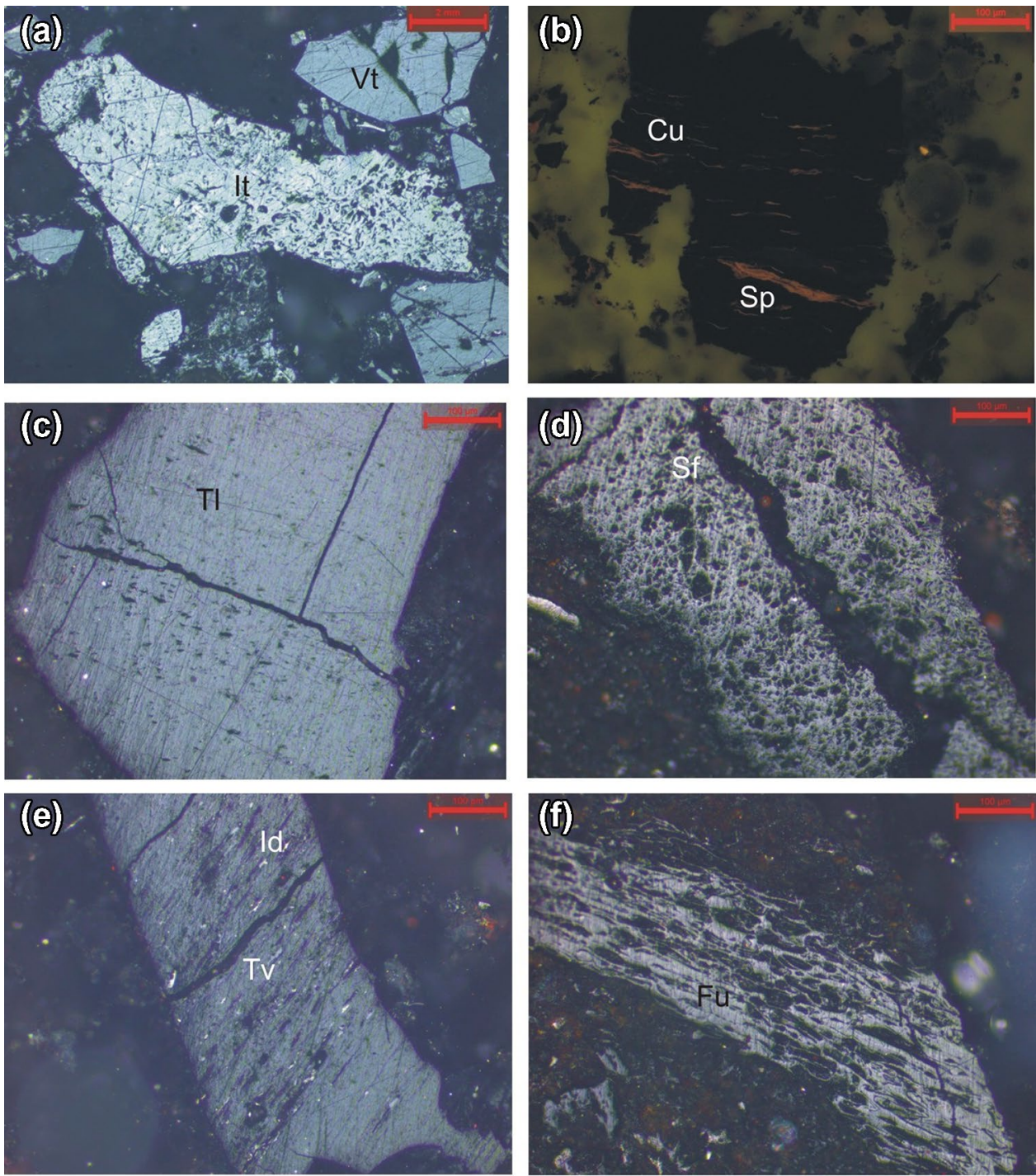

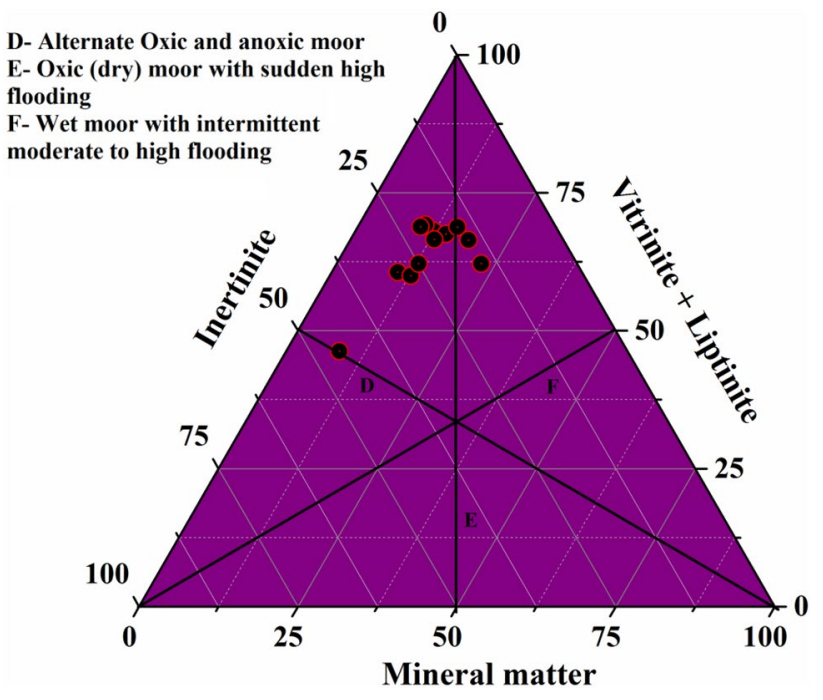

Fig. 7 Ternary facies diagram involving maceral and visible mineral matter contents after Kumar et al. 2018

\section{Coal quality analysis}

The gross calorific value, ultimate and proximate analyses were performed, and their results are summarized in Table 3. Due to the existence of significant quantity combustible component in coal samples, calorific value high is in all samples, and it varies from 5160 to $6840 \mathrm{cal} / \mathrm{gm}$. It can be illustrated from the various analyses sample encompasses lower moisture content, and it varies from 0.80 to $1.90 \%$. Samples also contain a moderate to high amount of ash percentage, and it varies from 16.90 to $32.60 \%$. Similarly, organic contents like volatile matter and fixed carbon vary from 7.20 to $22.40 \%$ and $51.70-70.50 \%$ (dry basis).

Samples have a significant quantity of carbon and hydrogen content; value varies from 78.59 to $92.16 \%, 3.40-5.36 \%$ on dry ash-free basis, respectively. The sulfur and nitrogen content of samples is below $1.16 \%$ and $2.71 \%$. The Van Krevelen diagram (Van Krevelen 1993) chart represents 
Fig. 8 Characteristics of the SEM pore-fracture system of the coal samples

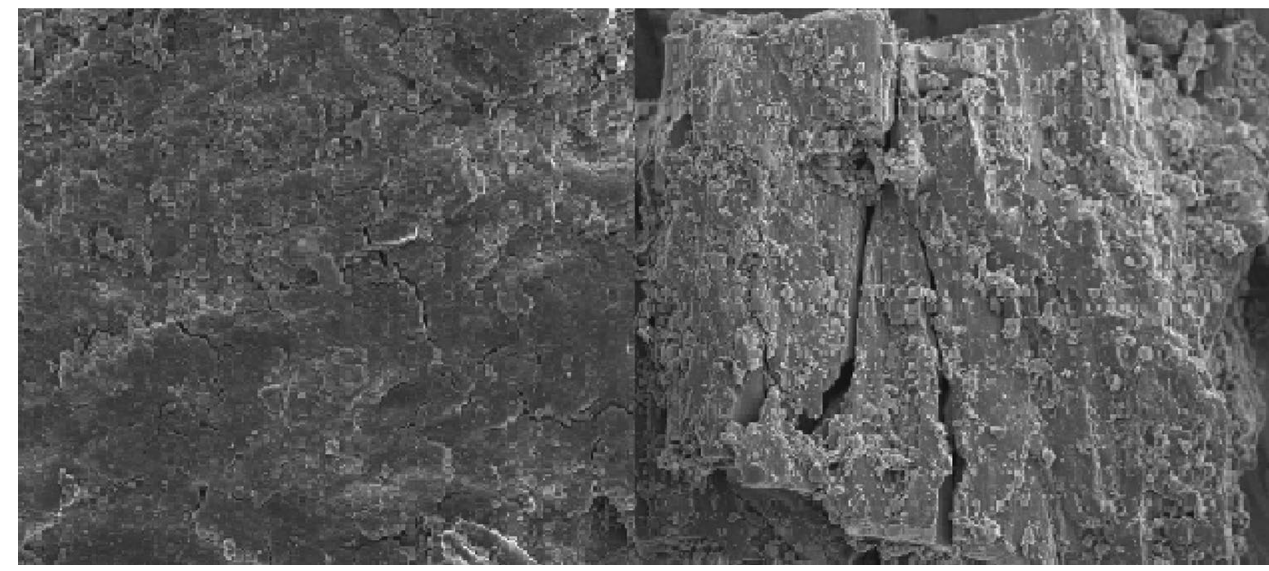

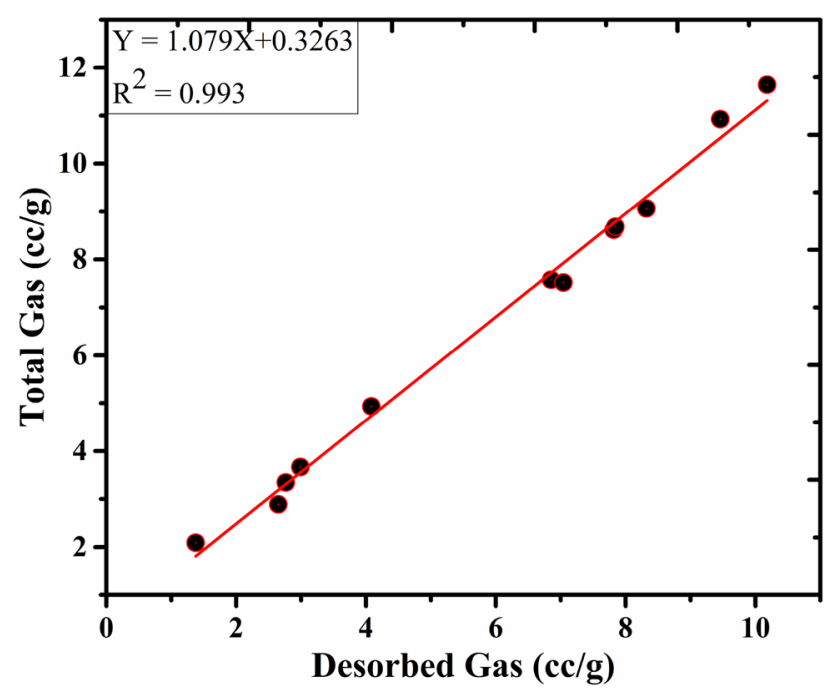

Fig. 9 Correlation between desorbed gas and total gas content for studied samples samples' maturity, kerogen type, and nature. The cross-plot between $\mathrm{H} / \mathrm{C}$ and $\mathrm{O} / \mathrm{C}$ shown in Fig. 10 demonstrates that the samples fall in bituminous rank and lie in the category of kerogen types III.

\section{Fourier transform infrared spectroscopy studies}

FTIR analysis not only provides information about functional groups, but it is also significant for the determination of hydrocarbon generation potential (Hossain et al. 2019; Kumar et al. 2018). "A" factor (aliphatic/aromatic bands) can evaluate the hydrocarbon-generating potential of coal, and the "C" factor primarily the ratio of carbonyl/carboxyl groups to the aromatic group and illustrate the maturity of coal. It has been seen in many studies that as the " $\mathrm{C}$ " factor value increases, the maturity level of coal decreases (Ganz and Kalkreuth 1987, 1991; Samad et al. 2020).
Table 3 Proximate and ultimate analysis of samples

\begin{tabular}{|c|c|c|c|c|c|c|c|c|c|c|c|c|}
\hline \multirow[t]{2}{*}{ S. No } & \multicolumn{4}{|c|}{ Proximate analysis, w (\%) } & \multicolumn{5}{|c|}{ Ultimate analysis, w (\%) daf } & \multicolumn{2}{|c|}{ Atomic ratio } & \multirow{2}{*}{$\begin{array}{l}\text { G.C.V } \\
\text { (cal/g) }\end{array}$} \\
\hline & M & A & $\mathrm{VM}$ & $\mathrm{FC}$ & $\mathrm{C}$ & $\mathrm{H}$ & $\mathrm{N}$ & $\mathrm{S}$ & $\mathrm{O}$ & $\mathrm{O} / \mathrm{C}$ & $\mathrm{H} / \mathrm{C}$ & \\
\hline 1 & 1.30 & 32.30 & 7.20 & 59.20 & 90.33 & 3.40 & 2.66 & 0.81 & 2.80 & 0.021 & 0.451 & 5160 \\
\hline 2 & 1.80 & 18.70 & 9.00 & 70.50 & 91.76 & 3.82 & 2.29 & 0.74 & 1.38 & 0.010 & 0.500 & 6230 \\
\hline 3 & 1.90 & 20.00 & 7.80 & 70.30 & 92.16 & 3.86 & 1.46 & 0.74 & 1.77 & 0.013 & 0.503 & 6150 \\
\hline 4 & 1.70 & 32.60 & 8.50 & 57.20 & 87.52 & 5.36 & 2.71 & 1.08 & 3.33 & 0.025 & 0.735 & 5200 \\
\hline 5 & 0.90 & 20.10 & 21.50 & 57.50 & 85.53 & 4.85 & 2.16 & 1.16 & 6.29 & 0.049 & 0.681 & 6820 \\
\hline 6 & 1.20 & 19.10 & 21.20 & 58.50 & 81.83 & 4.84 & 2.11 & 0.82 & 10.40 & 0.085 & 0.710 & 6700 \\
\hline 7 & 0.80 & 18.60 & 21.80 & 58.80 & 78.59 & 4.83 & 2.04 & 0.79 & 13.75 & 0.117 & 0.738 & 6750 \\
\hline 8 & 1.30 & 17.30 & 22.40 & 59.00 & 80.57 & 4.86 & 2.05 & 0.74 & 11.78 & 0.098 & 0.724 & 6840 \\
\hline 9 & 0.80 & 20.10 & 20.60 & 58.50 & 83.42 & 4.75 & 2.18 & 0.54 & 9.11 & 0.073 & 0.683 & 6700 \\
\hline 10 & 1.00 & 21.60 & 22.30 & 55.10 & 80.32 & 4.99 & 2.11 & 0.53 & 12.05 & 0.100 & 0.746 & 6300 \\
\hline 11 & 1.10 & 25.20 & 22.00 & 51.70 & 86.15 & 4.18 & 2.25 & 0.45 & 6.98 & 0.054 & 0.582 & 6280 \\
\hline 12 & 1.00 & 16.90 & 20.40 & 61.70 & 83.58 & 4.73 & 2.02 & 0.68 & 8.99 & 0.072 & 0.679 & 6840 \\
\hline
\end{tabular}

$M$ Moisture; A Ash; VM Volatile matter, $F C$ Fixed Carbon; ad-air dry basis; daf- dry ash-free basis 


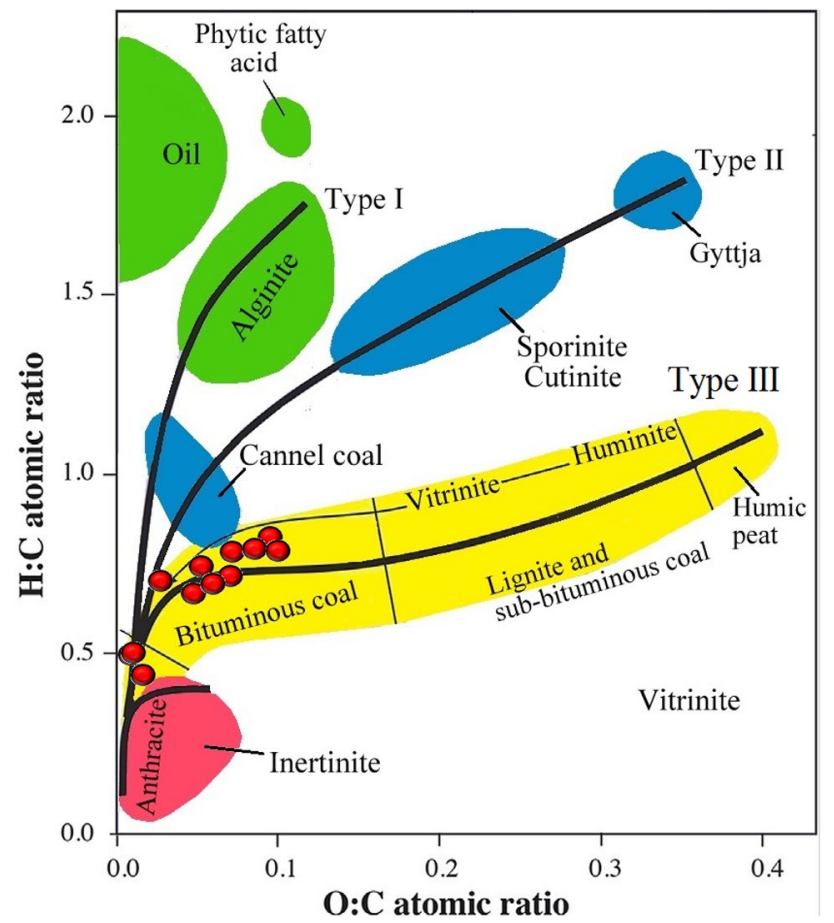

Fig. 10 Cross-plot between $\mathrm{H} / \mathrm{C}$ and $\mathrm{O} / \mathrm{C}$ atomic ratio for studied samples

The "A" factor and " $\mathrm{C}$ " factor can be easily determined by the following equation as given as follows (Varma et al., 2018):

$$
\begin{aligned}
& \text { A factor }=\frac{2930 \mathrm{~cm}^{-1}+2860 \mathrm{~cm}^{-1}}{1630 \mathrm{~cm}^{-1}+2930 \mathrm{~cm}^{-1}+2860 \mathrm{~cm}^{-1}} \\
& C \text { factor }=\frac{1710 \mathrm{~cm}^{-1}}{1710 \mathrm{~cm}^{-1}+1630 \mathrm{~cm}^{-1}}
\end{aligned}
$$

It was described in different studies that as the A factor value increases, the maturity decreases and the aliphatic nature increases in coal (Durand and Espitalié 1976; Esen et al. 2020; Lis et al. 2005). Identically, the C factor value decreases with maturity, which reveals a decrease in oxygenated components in coal. A factor $(>0.664)$ and $C$ factor $(>0.501)$ value of studied samples demonstrates that samples have moderate aromatic and aliphatic hydrocarbon (Chen et al. 2012; Yao et al. 2011). A factor and $\mathrm{C}$ factor indicate that types II and III kerogen are present in investigated samples (Misra et al. 2020; Varma et al. 2015b, 2018). A similar result found from the plot between atomic $\mathrm{H} / \mathrm{C}$ and $\mathrm{O} / \mathrm{C}$ of the coal samples demonstrates that the samples lie in the kerogen types II and III consecutively (Akanksha et al. 2020, 2017).

\section{Conclusion}

Based on the current examination, the following conclusions are drawn:

1. The hydrocarbon generation potential of the Sitarampur block was assessed using petrographic data. The petrographic examination illustrated that significant values of reactive macerals are present in samples, and its value varies from 67.57 to 81.10 vol. \% respectively. Similarly, the petrographic analysis also demonstrates that organic matter is dominated by the prominent source of aromatic hydrocarbon with a minor proportion of aliphatic hydrocarbon, making it suitable for hydrocarbon generation potential.

2. The petrographic analysis confirms the appearance of textinite and attrinite as a primary contributor to vitrinite macerals groups. Sporenite, cutinite, and resinite macerals were dominantly present in liptinite macerals groups. Similarly, semifusinite is the only visible maceral present in samples from the inertinite group.

3. Some positive correlations were also found between conversion, reactive macerals, and oil yield, which integrates the participation of various macerals during oil and gas generation in studied samples.

4. Fourier transforms infrared (FTIR) spectroscopy was significantly utilized in our study to determine various functional groups. "A" factor (aliphatic/aromatic bands) and " $\mathrm{C}$ " factor (carbonyl/carboxyl bands) value concluded that the sample has the lowest aromaticity and the highest hydrocarbon-generating potential, which was also validated by the Van Krevelen diagram.

5. The plots between $\mathrm{H} / \mathrm{C}$ and $\mathrm{O} / \mathrm{C}$ ratio in the Van Krevelen diagram indicate that the coal samples were lied in the type III kerogen and bituminous coal (gas prone zone). Which is also confirmed by the cross-plot between desorbed and total gas (cc/g).

6. The SEM analysis reveals the occurrence of several size pores and fracture and distribution in studied samples.

7. The studied samples of Sitarampur block were characterized by low moisture, high ash, and moderate volatile matter content in nature, which is suitable for methane production.

Funding This research received no specific grant from any funding agency.

\section{Declarations}

Conflict of interest No potential conflict of interest was reported by the authors. 
Open Access This article is licensed under a Creative Commons Attribution 4.0 International License, which permits use, sharing, adaptation, distribution and reproduction in any medium or format, as long as you give appropriate credit to the original author(s) and the source, provide a link to the Creative Commons licence, and indicate if changes were made. The images or other third party material in this article are included in the article's Creative Commons licence, unless indicated otherwise in a credit line to the material. If material is not included in the article's Creative Commons licence and your intended use is not permitted by statutory regulation or exceeds the permitted use, you will need to obtain permission directly from the copyright holder. To view a copy of this licence, visit http://creativecommons.org/licenses/by/4.0/.

\section{References}

Abudeif AM, Attia MM, Radwan AE (2016) New simulation technique to estimate the hydrocarbon type for the two untested members of Belayim Formation in the absence of pressure data, Badri Field, Gulf of Suez. Egypt Arabian Journal of Geosciences 9:218. https://doi.org/10.1007/s12517-015-2082-2

Akanksha SAK, Mohanty D, Jena HM, Panwar DS (2020) Prospective evaluation of hydrocarbon generation potential of Umarsar lignite. India Energy Sources, Part a: Recovery, Utilization, and Environmental Effects 42:664-675. https://doi.org/10.1080/ 15567036.2019.1588430

Akanksha SAK, Mohantya D, Jena HM (2017) Characterization of lignite for underground coal gasification in India Energy Sources. Part a: Recovery, Utilization, and Environmental Effects 39:1762-1770. https://doi.org/10.1080/15567036.2017. 1352630

Altowilib A, AlSaihati A, Alhamood H, Alafnan S, Alarifi S (2020) Reserves Estimation for Coalbed Methane Reservoirs: A Review Sustainability 12 doi:https://doi.org/10.3390/su122410621

Attia MM, Abudeif AM, Radwan AE (2015) Petrophysical analysis and hydrocarbon potentialities of the untested Middle Miocene Sidri and Baba sandstone of Belayim Formation. Badri Field, Gulf of Suez, Egypt Journal of African Earth Sciences 109:120 130. https://doi.org/10.1016/j.jafrearsci.2015.05.020

BP (2020) Statistical Review of World Energy 2020 BP London https://www.bp.com/content/dam/bp/business-sites/en/global/ corporate/pdfs/energy-economics/statistical-review/bp-statsreview-2020-full-report.pdf

CEA (2019) Central Electricity Authority, Ministry of Power, Government of India. 31 March 2019. Retrieved 31 August 2019. https://cea.nic.in/old/reports/circulars/2020/146.pdf

Chen Y, Mastalerz M, Schimmelmann A (2012) Characterization of chemical functional groups in macerals across different coal ranks via micro-FTIR spectroscopy. Int J Coal Geol 104:22-33. https://doi.org/10.1016/j.coal.2012.09.001

Crosdale PJ, Beamish BB, Valix M (1998) Coalbed methane sorption related to coal composition. Int J Coal Geol 35:147-158. https:// doi.org/10.1016/S0166-5162(97)00015-3

Durand B, Espitalié J (1976) Geochemical studies on the organic matter from the Douala Basin (Cameroon)-II. Evolution of Kerogen Geochimica Et Cosmochimica Acta 40:801-808. https://doi.org/10.1016/0016-7037(76)90032-6

Esen O, Özer SC, Soylu A, Ramazani Rend A, Fişne A (2020) Geological controls on gas content distribution of coal seams in the Kinık coalfield, Soma Basin. Turkey Int J Coal Geol 231:103602. https://doi.org/10.1016/j.coal.2020.103602

Evans C, Budwill K, J. Whiticar M (2020) Geological, Geochemical, and Microbial Factors Affecting Coalbed Methane. In: Wilkes H (ed) Hydrocarbons, Oils and Lipids: Diversity, Origin,
Chemistry and Fate. Springer International Publishing, Cham, pp 623-650. doi:https://doi.org/10.1007/978-3-319-90569-3_21

Fu H et al (2016) Geological characteristics and CBM exploration potential evaluation: a case study in the middle of the southern Junggar Basin. NW China J Nat Gas Sci Eng 30:557-570. https://doi.org/10.1016/j.jngse.2016.02.024

Ganz H, Kalkreuth W (1987) Application of infrared spectroscopy to the classification of kerogentypes and the evaluation of source rock and oil shale potentials. Fuel 66:708-711. https://doi.org/ 10.1016/0016-2361(87)90285-7

Ganz HH, Kalkreuth W (1991) IR classification of kerogen type, thermal maturation, hydrocarbon potential and lithological characteristics Journal of Southeast Asian Earth Sciences 5:19-28 doi:http://www.sciencedirect.com/science/article/ pii/074395479190007K

Gao L, Mastalerz M, Schimmelmann A (2014) Chapter -2 The Origin of Coalbed Methane. Coal Bed Methane-From Prospect to Pipeline. Elsevier Inc., Amsterdam, pp 7-29

Goraya NS, Rajpoot N, Marriyappan Sivagnanam B (2019) Coal Bed Methane Enhancement Techniques: A Review ChemistrySelect 4:3585-3601 doi:https://doi.org/10.1002/slct.201803633

Guyot RE (1978) Influence of coal characteristics on the yields and properties of hydrogenation products. Australia

Hossain HMZ, Sampei Y, Hossain QH, Yamanaka T, Roser BP, Sultan-Ul-Islam M (2019) Origin of organic matter and hydrocarbon potential of Permian Gondwana coaly shales intercalated in coals/sands of the Barapukuria basin. Bangladesh Int J Coal Geol 212:103201. https://doi.org/10.1016/j.coal.2019.05.008

Hou S, Wang X, Wang X, Yuan Y, Zhuang X, Wang X (2016) Geological controls on gas saturation in the Yanchuannan Coalbed Methane Field. Southeastern Ordos Basin, China Marine Petroleum Geol 78:254-270. https://doi.org/10.1016/j.marpetgeo.2016. 09.029

Jin J (1997) Shi S The development and prospective application of coal direct liquefaction for Chinese coals. Proc. Xiamen, China Coal Industry Publishing House, Internat. Symp. on Clean Coal Technology, p 379

Karacan CÖ (2009) Forecasting gob gas venthole production performances using intelligent computing methods for optimum methane control in longwall coal mines. Int J Coal Geol 79:131-144. https://doi.org/10.1016/j.coal.2009.07.005

Kiani A, Sakurovs R, Grigore M, Sokolova A (2018) Gas sorption capacity, gas sorption rates and nanoporosity in coals International Journal of Coal Geology 200:77-86 doi:https://doi.org/10.1016/j. coal.2018.10.012

Kotarba MJ, Clayton JL, Rice DD, Wagner M (2002) Assessment of hydrocarbon source rock potential of Polish bituminous coals and carbonaceous shales. Chem Geol 184:11-35. https://doi.org/10. 1016/S0009-2541(01)00350-3

Kumar J et al (2018) Coalbed methane reservoir characteristics of coal seams of south Karanpura coalfield. Jharkhand, India Int J Coal Geol 196:185-200. https://doi.org/10.1016/j.coal.2018.07.011

Li P, Zhang X, Li J, Zhao J, Huang J, Zhang S, Zhou S (2020) Analysis of the key factors affecting the productivity of coalbed methane wells: a case study of a high-rank COAL RESERVOIR IN THE CENTRAL and Southern Qinshui Basin. China ACS Omega 5:28012-28026. https://doi.org/10.1021/acsomega.0c03540

Lis GP, Mastalerz M, Schimmelmann A, Lewan MD, Stankiewicz BA (2005) FTIR absorption indices for thermal maturity in comparison with vitrinite reflectance R0 in type-II kerogens from Devonian black shales Organic Geochemistry 36:1533-1552 doi:https://doi.org/10.1016/j.orggeochem.2005.07.001

Mishra DK, Samad SK, Varma AK, Mendhe VA (2018) Pore geometrical complexity and fractal facets of Permian shales and coals from Auranga Basin. Jharkhand, India J Nat Gas Sci Eng 52:25-43. https://doi.org/10.1016/j.jngse.2018.01.014

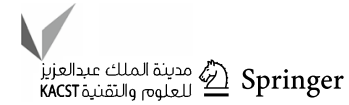


Misra S, Das SK, Varma AK, Mani D, Kalpana MS, Ekblad A, Biswas $S$ (2020) Multi-proxy approach on the hydrocarbon generation perspective of Barjora Basin. India Marine and Petrol Geol 112:104108. https://doi.org/10.1016/j.marpetgeo.2019.104108

Moore TA (2012) Coalbed methane: a review. Int J Coal Geol 101:36-81

Moore TA, Bowe M, Nas C (2014) High heat flow effects on a coalbed methane reservoir, East Kalimantan (Borneo). Indonesia International Journal of Coal Geology 131:7-31. https://doi.org/10. 1016/j.coal.2014.05.012

MPNG (2020) Ministry of petroleum and natural gas annual report 2019-20.

Ojha K, Mandal A, Karmakar B, Pathak AK, Singh AK (2013) Studies on the estimation and prospective recovery of coal bed methane from raniganj coalfield. India Energy Sources, Part a: Recovery, Utilization, and Environ Effects 35:426-437. https://doi.org/10. 1080/15567036.2010.512911

Painter PC, Snyder RW, Starsinic M, Coleman MM, Kuehn DW, Davis A (1981) Concerning the application of FT-IR to the study of coal: a critical assessment of band assignments and the application of spectral analysis programs. Appl Spectrosc 35:475-485. https:// doi.org/10.1366/0003702814732256

Panwar D, Saxena V, Singh A, Prashant, Yadav A (2016a) Seam quality and gas resource estimation in kulti block of Raniganj coal field West Bengal India International Journal of Engineering Research Science Technology 5:1-9

Panwar D, Saxena V, Singh A, Yadav A (2016b) Natural gas recovery: A case study of field scale development in Raniganj coal International Journal of Engineering Research Science Technology 5:51-57

Panwar DS, Saxena VK, Chaurasia RC, Singh AK (2017a) Prospective evaluation of coal bed methane in Raniganj coal field, India. Energy Sources, Part a: Recovery, Utilization, Environ Effects 39:946-954. https://doi.org/10.1080/15567036.2017.1279242

Panwar DS, Saxena VK, Rani A, Singh AK, Kumar V (2017b) Source rock evaluation of the Gondwana coals in Raniganj coalfield, India. Energy Sources, Part a: Recovery, Utilization, Environ Effects 39:1395-1402. https://doi.org/10.1080/15567036.2017. 1334105

Panwar DS, Saxena VK, Suman S, Kumar V, Singh AK (2017c) Physicochemical study of coal for CBM extraction in Raniganj coal field, India. Energy Sources, Part a: Recovery, Utilization Environ Effects 39:1182-1189. https://doi.org/10.1080/15567036.2017. 1314394

Panwar DS, Suman S, Singh AK, Saxena VK, Chaurasia RC (2020) Assessment of hydrocarbon generation potential of bituminous coal from Raniganj Basin. India Energy Sources, Part a: Recovery, Utilization, Environ Effects 42:824-834. https://doi.org/10.1080/ 15567036.2019.1588427

Radwan AE, Rohais S, Chiarella D (2021) Combined stratigraphicstructural play characterization in hydrocarbon exploration: A case study of Middle Miocene sandstones, Gulf of Suez basin. Egypt J Asian Earth Sci 218:104686. https://doi.org/10.1016/j. jseaes.2021.104686
Samad SK, Mishra DK, Mathews RP, Ghosh S, Mendhe VA, Varma AK (2020) Geochemical attributes for source rock and palaeoclimatic reconstruction of the Auranga Basin. India J Petrol Sci Eng 185:106665. https://doi.org/10.1016/j.petrol.2019.106665

Sharma S, Saxena A, Saxena N (2019) Introduction to Coal Bed Methane (CBM). In: Sharma S, Saxena A, Saxena N (eds) Unconventional Resources in India: The Way Ahead. Springer International Publishing, Cham, pp 5-10. doi:https://doi.org/10.1007/ 978-3-030-21414-2_1

Tissot BP, Welte DH (1984) From Kerogen to Petroleum. In: Tissot BP, Welte DH (eds) Petroleum Formation and Occurrence. Springer Berlin Heidelberg, Berlin, Heidelberg, pp 160-198. doi:https:// doi.org/10.1007/978-3-642-87813-8_10

Van Krevelen DW (1993) Coal: typology, physics, chemistry, constitution. Elsevier Amsterdam,

Varma AK et al (2015a) Petrographic characteristics and methane sorption dynamics of coal and shaly-coal samples from Ib Valley Basin. Odisha, India Int J Coal Geol 141-142:51-62. https://doi. org/10.1016/j.coal.2015.03.005

Varma AK, Biswas S, Patil DJ, Mani D, Misra S, Hazra B (2019) Significance of lithotypes for hydrocarbon generation and storage. Fuel 235:396-405. https://doi.org/10.1016/j.fuel.2018.07.111

Varma AK, Khatun M, Mendhe VA, Hazra B, Singh BD, Dayal AM (2015b) Petrographic characterization and langmuir volume of shales from Raniganj coal basin. India J Geol Soc India 86:283294. https://doi.org/10.1007/s12594-015-0313-5

Varma AK, Mishra DK, Samad SK, Prasad AK, Panigrahi DC, Mendhe VA, Singh BD (2018) Geochemical and organo-petrographic characterization for hydrocarbon generation from Barakar Formation in Auranga Basin. India Int J Coal Geol 186:97-114. https://doi. org/10.1016/j.coal.2017.12.002

Wang Q, Su X, Su L, Zhou F (2020) CBM geological characteristics and exploration potential in the Sunan Syncline block, southern north China basin Journal of Petroleum Science and Engineering 186:106713 doi:https://doi.org/10.1016/j.petrol.2019.106713

Yan J, Meng Z, Zhang K, Yao H, Hao H (2020) Pore distribution characteristics of various rank coals matrix and their influences on gas adsorption. J Petrol Sci Eng 189:107041. https://doi.org/10. 1016/j.petrol.2020.107041

Yao S, Zhang K, Jiao K, Hu W (2011) Evolution of coal structures: FTIR analyses of experimental simulations and naturally matured coals in the Ordos Basin. China Energy Explor Exploit 29:1-19. https://doi.org/10.1260/0144-5987.29.1.1

Yee D, Seidle JP, Hanson WB (1993) Gas sorption on coal and measurement of gas content: Chapter 9. American Association of Petroleum Geologists. Tulsa, Oklahoma,

Publisher's Note Springer Nature remains neutral with regard to jurisdictional claims in published maps and institutional affiliations. 